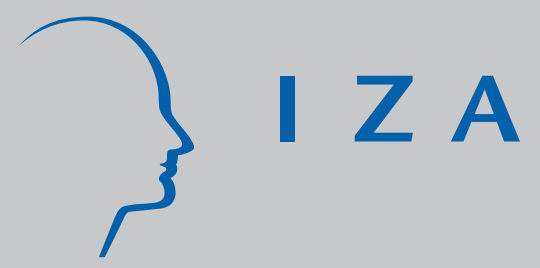

IZA DP No. 22

The Economics of Hospital Trips and Health Care Reform

Andreas Million

Ralph Rotte

Klaus F. Zimmermann

September 1998 


\title{
The Economics of Hospital Trips and Health Care Reform
}

\author{
Andreas Million \\ Ralph Rotte \\ Klaus F. Zimmermann
}

Discussion Paper No. 22

September 1998

IZA

P.O. Box 7240

D-53072 Bonn

Germany

Tel.: +49-228-3894-201

Fax: +49-228-3894-210

Email: iza@iza.org

This Discussion Paper is issued within the framework of IZA's research area The Welfare State and Labor Markets. Any opinions expressed here are those of the author(s) and not those of the institute. Research disseminated by IZA may include views on policy, but the institute itself takes no institutional policy positions.

The Institute for the Study of Labor (IZA) in Bonn is a local and virtual international research center and a place of communication between science, politics and business. IZA is an independent, nonprofit limited liability company (Gesellschaft mit beschränkter Haftung) supported by the Deutsche Post AG. The center is associated with the University of Bonn and offers a stimulating research environment through its research networks, research support, and visitors and doctoral programs. IZA engages in (i) original and internationally competitive research in all fields of labor economics, (ii) development of policy concepts, and (iii) dissemination of research results and concepts to the interested public. The current research program deals with (1) mobility and flexibility of labor markets, (2) internationalization of labor markets and European integration, (3) the welfare state and labor markets, (4) labor markets in transition, (5) the future of work, and (6) general labor economics.

IZA Discussion Papers often represent preliminary work and are circulated to encourage discussion. Citation of such a paper should account for its provisional character. 
IZA Discussion Paper No. 22

September 1998

\section{ABSTRACT \\ The Economics of Hospital Trips and Health Care Reform}

One cornerstone of current attempts to reform the German public health care system by introducing private insurance schemes is the assumption that economic incentives play an important role in individual decision-making about using medical help. This hypothesis is examined for the case of demand for hospital care which covers the largest part of public insurance expenditures. The paper applies various methods for count data analysis of the frequency of hospital trips. Contrary to comparative studies for other countries, we find that there is no significant impact of insurance schemes on hospitalization. Therefore, the current efforts to reduce expenditures by relying on consumer behaviour are unlikely to work.

JEL Classification: I11, I12, I18

Keywords: health care reform, hospitalization, hospital cost inflation

Klaus F. Zimmermann

IZA

P.O. Box 7240

D - 53072 Bonn

Germany

Tel.: +49-228-3894-201

Fax: +49-228-3894-210

email: Zimmermann@iza.org 


\section{Introduction}

Like all other industrialized countries (Cutler, 1994), Germany has experienced massively rising costs of its health security system in recent years. Although official statements do not tire of emphasizing the major achievements of the German public health system, which provides a high level supply of health care for 72 million citizens, including retirees and children (Federal Ministry of Health, 1997a), aggravating financial problems of the contribution-based system have resulted in an undisputed need for reform. In fact, the success of public and private health insurance (with additional 8 million insured people) covering about 97 per cent of the population, while e.g. in the United States about 15 per cent remain uninsured (Federal Ministry of Health, 1997b), has been accompanied by total health expenditures soaring from 4.2 per cent of GNP in 1970 and 6.5 per cent in 1990 to about 8.3 per cent in 1996 (IDW, 1997). In the same period, despite average contributions rising from 8.2 per cent of gross income (1970) to 12.5 per cent (1990) and 13.6 per cent (1996), public health insurance has been running persistent deficits in recent years, which amount annually for about DM 4 to 5 billion in West Germany and for DM 2 to 3 billion in the former GDR (IDW, 1997; Federal Ministry of Health 1997c).

In order to cope with the cost inflation of public health care and to relieve firms and employees from rising additional labour costs, the Federal Government has introduced a package of reform measures in three Health Reform Acts since 1988. The most recent of those acts tries to foster private insurance elements within the overall framework of public health insurance by aiming at higher flexibility for public health insurance companies and increasing copayments for actual medical care. The highest share of health insurance outlays is for hospital care, amounting for DM 101.7 billion in 1995 (Arnold and Paffrath, 
1997), or about one third of all outlays. The reform strategy chosen by the Federal Government implies improvements in the cost-awareness of potential patients, and lower incentives to freeride the system that provides the whole range of medical supply for a largely constant contribution. Despite the emphasis on supply-side elements of hospital inflation which can also be found in the literature (e.g. Evans and Walker, 1972; Evans, 1991), this recent political focus makes us concentrate on the demand-side in this paper. It therefore analyzes the impact of private insurance schemes on the individual demand for hospital care.

Section 2 will set the general theoretical framework and outlines selectively the sources of hospital inflation. Section 3 surveys the previous empirical findings. Section 4 explains the theoretical model under test. In section 5, the German health care system and its recent reform efforts are reviewed, and section 6 presents the data set. Section 7 contains the econometric models that are at our disposal and explains model specifications and tests. Section 8 summarizes our empirical findings and section 9 concludes.

\section{Economic Theory and Hospital Cost Explosion}

The main approaches for explaining the rise in the cost of health care in general and of hospital care in particular, have been reviewed in survey articles by Weisbrod (1991), Cutler (1995) and Feldstein (1995). Most of the literature concentrates on the situation of the United States since the implementation of the Medicare and Medicaid programs in 1966 (Grossman, 1982; Feldstein, 1995), which may not seem appropriate for understanding cost escalation within a European-type social insurance based system. For 
an introductory overview of European health care systems see van Doorslaer and Wagstaff (1992) and Wagstaff and van Doorslaer (1992). Nevertheless, since most U.S. contributions focus on potential problems of state-intervention in health care, the arguments presented provide a suitable starting point for the study of theoretical and empirical incentives of public health insurance in the case of German hospital care.

The most frequently followed line of argument draws on the propelling role of social insurance for the demand for hospital care. Feldstein (1971), for instance, argues that the basic source of hospital cost inflation is the pressure of rising demand induced by increases in insurance coverage and the availability of hospital oriented specialists. Both were made possible by the introduction of public health insurance schemes resulting in fact in subsidization of individual demand as well as in an increase of money provided for special medical services. Manning et al. (1987) emphasize that public insurance schemes have resulted in market failure and 'overconsumption' of health care, due to a lack of costsharing schemes, since the insured individuals need not to contribute to the actual costs they cause to the system.

Moreover, hospitals themselves are said to be responsible for the rise in expenditure (Klarmann, 1969; Davis, 1971). Having realized that general social insurance enabled them to pass costs on to the general public instead of to specific patients, they have lost incentives to use supplies economically and have simultaneously tried to maximize their revenues. Again, public insurance plays a major role since it results in costunelastic demand and thus allows suppliers of health goods to set prices alone.

Rising wages are also viewed as a decisive element of hospital cost inflation (Davis, 1971). Increasing wages are then attributed to increased unionization (especially 
in the 1960s and 1970s), tightening labour markets for hospital personnel apart from doctors, and a change of the composition of the employees to more highly skilled and hence better paid personnel.

Finally, rapid technological advance is seen as a main factor of hospital inflation (Weisbrod, 1991; Newhouse, 1992). By enabling industry to finance their R\&D expenditures via increased prices affordable after the improvements in general social insurance, expenditures for medical care, especially in inpatient hospital care, have soared. Due to technological, non-price competition of hospitals in a "medical arms race" (Dranove et al., 1992), public health insurance shifted more and more to payments that were largely independent of costs caused by any particular patient, and thus created incentives for the R\&D sector to invest massively in medical technologies of higher quality but of far higher costs.

\section{Previous Empirical Results}

There has been a large amount of empirical work on the actual factors of hospital inflation in the literature. Feldstein (1971) concluded that insurance coverage and increased availability of hospital services had led to significant increases in demand resulting in demand pull inflation. An overview of important results on the price elasticity of health care demand is given by Hunt-McCool et al. (1994). After the Medicaid and Medicare programs had covered all of the U. S., the overall negative price elasticity seems to have fallen close to zero (Atri and Lahiri, 1986). In brief, there seems some empirical evidence that improved insurance coverage is a driving force of hospital inflation. One can conclude from this that an increase in cost sharing in order to weaken the moral hazard problem 
should have a decreasing effect on demand. Taking into account the basic problems of social insurance mentioned above, this should be especially relevant in the case of public health insurance.

While most studies have concentrated on the effects of the introduction of social insurance coverage and of existence of insurance per se, differences in the demand of publicly and privately insured people have hardly been studied so far. For Australia, Cameron et al. (1988) find that for a broad range of health services including hospital care, there is a higher usage of services by people with insurance policies with more generous coverage, which includes private insurance schemes. This is, however, conditional on the preceding choice of insurance and thus a problem of self-selection as well as of moral hazard. For Germany, on the other hand, PohImeier and Ulrich (1995) conclude that private insurance has a significantly negative effect on the decision of whether to see a general practitioner or not. Concerning the individually more serious question of hospitalization there is no empirical information on the effect of the kind of insurance scheme so far. Based on previous work by Phelps (1976), the actual choice of health insurance has also been a topic in the literature. Propper (1989) and Cameron and Trivedi (1991), for example, analyze the determinants of the demand of different insurance regimes in England and Wales, and Australia, respectively. Here, however, national institutional frameworks are of decisive importance (Cameron et al., 1988), which is why their results cannot be easily transferred to the German context.

Concerning other variables, Rosett and Huang (1972), and Acton (1975) claim education has a negative effect, while Wagstaff (1986) suggests a positive impact on demand, and Cameron et al. (1988) and Hunt-McCool et al. (1994) find inconsistent or no 
significant effects at all. The same is true for income having positive, negative or no significance in Rosett and Huang (1972) and Cameron et al. (1988), Acton (1975) and Atri and Lahiri (1986), and Feldstein (1977) and Hunt-McCool (1994), respectively. Even age, which may be intuitively seen as a driving element for hospital care demand, has no clear empirical relevance, with Acton (1975) finding a slightly negative and Hunt-McCool (1994) a positive effect. The results of Wagstaff (1986) and Cameron et al. (1988) indicate no significant impact of age on hospitalization.

\section{Modelling the Hospitalization Decision}

In order to model the individual demand for hospitalization we follow the basic idea of Grossman's (1972) seminal work which has become the benchmark approach to economic medical care demand (Grossman, 1982; Muurinen, 1982; Wagstaff, 1986). In Grossman's model, demand for health is seen as an individual investment decision similar to standard human capital theory. The individual inherits an initial stock of health capital which depreciates over time. The depreciation can be slowed down or even reversed by realizing investment projects augmenting one's health. The demand for health investment is generally equated with the demand for medical care in the literature. The individual maximizes utility from health given the production function of health and a budget constraint.

Typically, the resulting structural demand for health will then be of the following form (Wagstaff, 1986):

$$
\ln M(t)=\alpha_{0}+\alpha_{1} \ln H(t)+\alpha_{2} \ln w(t)+\alpha_{3} \ln P(t)+\alpha_{4} t+\alpha_{5} X+\alpha_{6} E+u(t)
$$


M represents the individual demand for health care which depends on the existing stock of health capital $\mathrm{H}$, the wage rate $\mathrm{w}$, the price of medical care $\mathrm{P}$, a time trend $\mathrm{t}$ reflecting age, a vector of environmental variables X (e. g. working conditions), education $\mathrm{E}$, and a stochastic error term $u$. Following the basic concept of health being a capital stock creating utility, low levels of $\mathrm{H}$ should induce a higher demand for investment, and this would imply a negative sign. $\alpha_{2}$ is expected to be positive, since a higher wage rate leads to increased returns from work and thus from health. Higher prices of health investment to be paid by the individual should decrease demand, which suggests that $\alpha_{3}$ is negative. Following the moral hazard argument, insurance coverage in general and social insurance schemes in particular should decrease individual health care prices and thus increase demand. The rate of depreciation for the health capital stock increases with age. This implies that $\alpha_{4}$ is positive. $\alpha_{5}$ should be positive if environmental factors are harmful for one's health and thus increase health depreciation. Finally, $a_{6}$ is expected to be negative since, according to the Grossman model, education has a positive impact on wages as well as on the individual productivity of health investment (Muurinen, 1982).

Following Cropper (1977), however, one could also expect investments in health to decrease the probability of illness, i.e. the demand in actual ambulatory and especially in hospital care. One may therefore view hospital trips as a consequence of neglected investments in health, since hospitalization may simply be the consequence of no prophylactic efforts. According to this view, health production is home production. Taking these qualifications into account, the structural demand for hospital trips $T$ (with realizations $0,1,2, \ldots)$ are modelled by

$$
T(t)=\beta_{0}+\beta_{1} H(t)+\beta_{2} y(t)+\beta_{3} I(t)+\beta_{4} t+\beta_{5} X+\beta_{6} E+\beta_{7} Z+u(t),
$$


where $y$ is income, and I represents insurance coverage; and $Z$ is an additional vector of common human capital control variables. Contrary to model (1), we expect $\beta_{2}$ to be negative now. The impact of more generous insurance coverage based on the relation of individual costs and benefits should result in a positive $\beta_{3}$.

When looking at individual behaviour in health care demand, one must also consider the influence of medical factors and the doctors' advice. Concerning hospitalization, even more than in ambulatory services, medical reasons will be the most important causes for demand. Contrary to PohImeier's and Ulrich's (1995) reasoning about the two-step decision-making process in the demand for ambulatory services, we think that due to the medical seriousness of hospitalization, the initial decision whether or not a patient should seek and be granted admission to a hospital, is first of all a question for the doctors. Assuming that staying in a hospital per se improves an individual's health, the actual intensity of care (i. e. frequency and duration of consecutive hospital trips) may then depend to a higher degree on the patient's economic incentives. Patients may well insist on being discharged as early as possible, or decide about their perceived need for after-treatment. One can therefore expect a systematic difference between the occurrence of hospital trips at all, and the number of realized ones. Econometric modelling of the frequency of hospital trips can take care of this potentially important difference by applying a hurdle model. A precondition of this approach, however, is the implicit assumption that every individual actually faces a situation of health care choice. This may in fact not be convincing for some groups of people who have no reason at all to consider going to hospital, e.g. healthy persons. One should therefore also consider an alternative way of modelling the additional special aspects of the occurrence of no hospital trips at all. We 
use a zero-inflated Poisson model here which explicitly takes account of the possibility that a number of individuals do not have any motivation to go to hospital.

Finally, there has been some concern about a distinct group of potential hospital patients, the chronically ill. Recent examples in the literature include Dowd et al. (1991), Krupnick and Cropper (1992), Newhouse et al. (1993), Fox (1993), and Tolley et al. (1994). First, the chronically ill are considered to be the most expensive group due to their high frequency of hospital trips. Second, from an economic point of view, one can argue that persons with chronic conditions face specific incentives which need a separate investigation, e. g. their potentially higher basic need for hospitalization due to a principally lower level of health capital.

\section{The German Health Insurance System and its latest Reform}

The public health insurance system in Germany is based on 607 self-administering corporations (Krankenkassen) which cover almost 90 per cent of the population. 507 of them are firm-based, providing insurance for the employees of big enterprises (Federal Ministry of Health, 1997a). In principle, there is a legal obligation for everyone to be insured either in the public scheme or in a private insurance company. Public insurance is compulsory for most people except for four major groups (Federal Ministry of Health, 1997d): People with a monthly income of less than DM 610 in Western Germany or less than DM 520 in Eastern Germany, as well as self-employed apart from special cases like peasants, artists and freelance journalists are not obliged to be health insured. Private insurance can be chosen by civil servants and by employees whose monthly income exceeds currently DM 6,150 in Western Germany or DM 5,325 in the five new Länder 
(states). Everyone, however, has the opportunity to participate voluntarily in the public scheme. Membership in public health insurance does not pre-empt additional private insurance coverage if desired, for example for single-room care in hospital. Nevertheless, there is in principle no discrimination of public insurance members as far as coverage or doctors' selection is concerned.

Public insurance is financed by solidarity-based contributions defined as a fixed percentage of income without any direct link between contribution and amount of services used. Contributions are split evenly between employee and his employer, which has made health insurance contributions one major target of claims of too high labour costs in Germany. Since the Krankenkassen are linked through a joint redistribution network, contribution rates do not vary much within the public scheme. In general, by paying his contributions a member of a public insurance corporation obtains the right to use all necessary medical services independent of their actual costs. The same holds for nonworking spouses and children of members. A second specialty of the public health system is the role of the regionally organized 20 Allgemeine Ortskrankenkassen (AOKs). Despite basic freedom of choice between the various public health insurance corporations since 1996, most corporations apart for the AOKs have been able to hold up some kind of traditional basic restrictions for admission of new members, thus reducing their risks. The AOKs, on the other hand, are obliged to accept everyone who does not choose another corporation and therefore provide also services for the highest health risks. According to economic theory, one should therefore expect special adverse selection problems of the German health insurance system resulting from the obligatory risk ignorance of the AOKs as well as from the two groups of insured self-employed and 
voluntary members of the public scheme. A special moral hazard problem of the system may be based on the missing link between contribution and services, and of the privileged status of family members.

Due to growing financial strains, there have been 46 reform acts with more than 6,800 changes of specific rules of the public health insurance system since 1977 (Federal Ministry of Health, 1997e). The most recent attempt, the Health Insurance Reorganization Act of 1997, aims, among other novelties, at higher copayments of patients as well as at increased flexibility for the Krankenkassen in designing their contracts. In the case of hospital care, individual daily copayments, which are limited to 14 days a year, have been increased from DM 12 to DM 17 in Western Germany, and from DM 9 to DM 14 in Eastern Germany. Moreover, public corporations are allowed to introduce reimbursement schemes in order to increase incentives to minimize the use of services.

The basic idea is to foster typical private insurance elements within the public insurance scheme and thus reduce "overconsumption" incentives resulting from the solidarity principle of public insurance. Since, in the case of hospital care, average per capita expenditures of private insurance companies amount for just two thirds of those for members of the public insurance scheme, this idea is promising at first sight (IDW, 1997). Nevertheless, it seems questionable not to take into account the special institutional prerequisites of the public insurance system whose fundamental elements, including family insurance and solidarity, are basically undoubted in most of the political discussion. We therefore address the empirical question whether, taking into account the different structure of the insured populations, private insurance elements really lead to a lower demand for hospital care. 


\section{The Data Set}

Our data set which has been used first in Geil et al. (1997) is a sample of 30,590 observations on 5,180 individuals from eight waves from the German Socio-Economic Panel Study (GSOEP) providing yearly microdata on a representative level of the population living in the Federal Republic of Germany since 1984 (Wagner et al., 1993). The sample contains information about adults (females and males) aged 25 to 64 , thus excluding children, students and retired people. Tables 1 and 2 provide an overview of the variables in the dataset and of their descriptive statistics. The basic information about the individual demand for hospitalization is a person's yearly number of hospital trips. A hospital trip is defined as accession to a hospital for at least one overnight stay. We also study the subsample of 1,480 chronically ill persons; descriptive statistics for this subgroup are given in Table 3.

We distinguish seven forms of insurance contracts and coverage. There is private insurance in general, private insurance with copayment obligations, and additional private insurance as a complement to public insurance. As far as the public insurance status is concerned, there is additional information whether an individual is an automatically insured family member, paying voluntary member, and member of an AOK. Information on one's health status is provided by two dummies for persons being chronically ill or handicapped.

The environmental factors of the Grossman model are represented by five job status variables (working or unemployed, blue collar workers, white collar workers, civil servants, self-employed) and by two dummies for part-time employment and distance to 
the city center which we take as a proxy for the distance of one's place of residence to the a hospital.

In order to control for an individual's health status, the data set contains two variables indicating presence of a chronic condition or a handicap. By using these two dummy variables we intend to avoid fundamental problems associated with the selfreported satisfaction with one's health on a scale from 0 to 10, which is also available in the GSOEP. Subjective health satisfaction may well be endogenous, and measurement may be inconsistent over individuals due to incentives to cheat (e.g. in order to justify disability retirement or unemployment) and a lack of an objective catalogue of criteria for the health assessment.

Education is covered by two variables indicating the level of formal education a person has received. The two criteria here were graduation from a secondary school and holding a degree from a technical college or university. Additionally, there are dummies for having passed an apprenticeship training and for working in a health-related job. Finally, there is information about age, number of children below 16 in the household, household net income and dummies for male and married. In order to cover potential differences in behaviour of varying cultural backgrounds, we also distinguish between Germans, foreigners from western countries and those from the rest of the world.

\section{Count Data Models and Specification}

Our endogenous variable, the number of hospital trips in each year, is discrete and nonnegative, which suggests the use of count data estimation methods. An overview on recent developments in count data modelling is given by Winkelmann and Zimmermann 
(1995). In this section we briefly outline the approaches used for better reference to the reader, and explain the modelling strategy.

The natural first way of modelling a count data problem is the Poisson model with

$$
P(Y=y)=f(y)=\frac{\exp (-\lambda) \lambda^{y}}{y !}, \quad \lambda \in \mathbb{R}^{+}, y=0,1,2, \ldots
$$

and

$$
\lambda_{i}=\exp \left(x_{i} \beta\right) \quad i=1, \ldots, n
$$

where $x_{i}$ is a vector of observed covariates and $\beta$ a vector of coefficients. The exponential form ensures $\lambda$ to be nonnegative.

The conceptual problems with the Poisson model have been largely discussed in the literature (e. g. Cameron and Trivedi, 1986; Mullahy, 1986; McCullagh and Nelder, 1989). The two most important failures of the simple Poisson approach are the assumption that the intensity of the Poisson process is a deterministic function of the covariates alone, and that events occur randomly over time. Thus, neither unobserved heterogeneity nor any influence of occurrences on the probability of future events is addressed. Both problems lead to a violation of the basic Poisson assumption of the equality of variance and mean.

In order to overcome these weaknesses of the Poisson model and allow for additional variation, compound Poisson models have been developed which introduce an additional error into the simple Poisson framework. Let

$$
\tilde{\lambda}_{i}=\exp \left(x_{i} \beta+\varepsilon_{i}\right)=\exp \left(x_{i} \beta\right) u_{i},
$$


where the error $u_{i}$ captures unobserved heterogeneity and is uncorrelated with the explanatory variables. The distribution of $y$ is then a mixture distribution. If $u_{i}$ is gamma distributed with $\Gamma(\alpha, \alpha)$ then $y_{i}$ follows a negative binomial distribution with

$$
f\left(y_{i} \mid \alpha, \lambda_{i}\right)=\frac{\Gamma\left(\alpha+y_{i}\right)}{\Gamma(\alpha) \Gamma\left(y_{i}+1\right)}\left(\frac{\alpha}{\lambda_{i}+\alpha}\right)^{\alpha}\left(\frac{\lambda_{i}}{\lambda_{i}+\alpha}\right)^{y_{i}}
$$

and

$$
\operatorname{Var}\left(Y_{i} \mid x_{i}\right)=E\left(Y_{i} \mid x_{i}\right)+\sigma^{2}\left[E\left(Y_{i} \mid x_{i}\right)\right]^{k+1}
$$

Assuming that the dispersion-parameter $\sigma=\alpha^{-1}$, Cameron and Trivedi (1986) denote this special negative binomial model as NEGBIN II which nests the standard Poisson model. (In this paper, we refer to this as the NEGBIN model.)

In order to capture the potential differences between zero and at least one occurrence of hospital trips, a hurdle Poisson model is used (Johnson and Kotz 1969; Mullahy 1986). This is achieved by combining a dichotomous model determining the binary outcome of the count being zero or positive with a truncated-at-zero Poisson model for strictly positive occurences.

The probability distribution of the hurdle model is given by

$$
P(Y=0)=f_{1}(0)
$$

and

$$
P(Y=y)=f_{2}(y) \frac{1-f_{1}(0)}{1-f_{2}(0)}=\Phi f_{2}(y), \quad y=1,2, \ldots,
$$


where $\mathrm{f}_{1}$ and $\mathrm{f}_{2}$ are probability distribution functions for nonnegative integers governing the hurdle part and the process once the hurdle has been passed, respectively. The numerator of $\Phi$ gives the probability of crossing the hurdle and the denominator is a normalization for $\mathrm{f}_{2}$. Here, we use a censored Poisson specification for the bivariate first step with $\lambda_{1}=\exp \left(x \beta_{1}\right)$, and a truncated-at-zero Poisson distribution with $\lambda_{2}=\exp \left(x \beta_{2}\right)$ for the behaviour once the hurdle has been crossed.

Ordinary count data models may not accurately take account of a data situation with excess zeros because there may be an additional different data generating process influencing the occurrence of zero events. Excess zeros can basically occur due to two basic reasons: First, an individual may not undertake any hospital trips in the period of time we observe, but may well be hospitalized in another period. Second, there may be individuals who would never go to a hospital whatever the incentives according to our model may be. Following Lambert (1992), we therefore use a zero-inflated-Poisson model (ZIP) which assigns an additional probability $\mathrm{p}_{\mathrm{i}}$ to the occurrence of zero so that $\mathrm{Y}_{\mathrm{i}} \sim 0$ with probability $\mathrm{p}_{\mathrm{i}}$ and $\mathrm{Y}_{\mathrm{i}} \sim$ Poisson $\left(\lambda_{\mathrm{i}}\right)$ with probability $1-\mathrm{p}_{\mathrm{i}}$. Consequently,

$$
\begin{gathered}
P(Y=0)=p_{i}+\left(1-p_{i}\right) \exp (-\lambda) \\
P(Y=y)=\left(1-p_{i}\right) \frac{\exp (-\lambda) \lambda^{y}}{y !}, \quad y=1,2, \ldots
\end{gathered}
$$

The occurrence of zero is then considered to be determined by a splitting distribution different from Poisson, e. g. the logistic or the normal distribution depending on $v_{i}$, where $v_{i}$ is defined either as $\tau \beta$ ' $x_{\mathrm{i}}$ in the so-called ZIP $(\tau)$ or as $\gamma \mathrm{Z}_{\mathrm{i}}$ in the ZIPB model with an independent regime split. Note that $\tau$ represents one single additional parameter while $\gamma$ is a whole new parameter vector by which one can include a completely new set of explaining covariates based on theoretical considerations. Since there 
is no theoretical economic justification for introducing additional variables, and since we faced serious convergence problems with our data when using our standard variables, we apply the logistic and the normalZIP $(\tau)$ here. A negative value for $\tau$ means that for variables with negative (positive) coefficients, the additional probability of not going to hospital rises (decreases).

Following the discussion in section 2 , we concentrate on the impact of insurance on the number of hospital trips. The effects are measured by a set of dummy variables. Choosing private insurance as the reference, there is first a dummy measuring the relative effect of public insurance (compulsory, voluntary or as a family member). Moreover, there is the group of $A O K$ members, the insurance companies that are legally obliged to insure all risks. Second, there are those with voluntary additional coverage through a private scheme (Additional). We interact these two dummies (AOK, Additional) with the dummies Public, Voluntary and Family in order to study the special group effects.

Our original suspicion that a chronic poor health condition could be a result of previous behaviour in health investment and thus a consequence of the insurance scheme chosen was not confirmed when controlled for. Neither was there high correlation between the insurance variables and Chronic, nor did an exclusion of this variable change estimation results significantly. Hence, chronic diseases can be regarded as exogenous factors of health status. Thus, there seems to be no problem with including the insurance variables and the Chronic variable jointly in our estimations.

We have split the total sample into males and females, and have replicated our estimations. This is justified by the performance of the separated models compared to the joint sample. In order to carry out the comparison, we sum up the loglikelihood values of the separate models and apply a simple likelihood-ratio test. The results suggest that separate estimation is preferred to an analysis of the total sample (Table 4). 
In proceeding from the cross-section Poisson to technically more sophisticated models, we also compared the performance of the simple basic model against that of the NEGBIN, and the ZIP $(\tau)$ models (Table 5). The tests all suggest that the simple Poisson framework is not adequate. We thus concentrate on the results of the NEGBIN and ZIP $(\tau)$ estimation for the gender-specific samples of the total data set and of the chronically ill, each of which covers a special theoretical problem of the demand for hospitalization. Comparisons of the model performance by using the AIC showed that there is no model which is clearly superior to the other approaches (Table 6).

\section{Estimation Results}

Our principal findings for the whole data set and for the chronically ill are reported in Tables 7 to 9. Basically, there are no striking differences between the detected relevant variables in the three model classes we have applied, although the respective behavioural framework is quite different.

From Table 7, it becomes obvious that age does not seem to have a significant impact on the decision on hospitalization for men. There is, however, a significant positive effect for women in general which is in accordance with traditional theory. Concerning the insurance variables we can see that the incentives provided by coverage is not dramatically relevant in real world decision-making. In principle, there are no significant effects of co-payment in private schemes or of the different kinds of public insurance. Only for women, we have found a significant effect for compulsory and voluntary membership in the public insurance and for AOK membership. But while the former fulfills the expectations, the two latter ones, contrary to our theoretical considerations, are negative. The choice of public insurance coverage for people with an income exceeding the institutional boundary of DM 6,150 and the automatic coverage of family members do not result in increased demand for hospitalization. Again, men do not show any reaction on insurance incentives. It is interesting that 
insurance basically plays not significant role according to the cross-section estimation techniques applied here. Taking account of potential correlation between individuals' responses over the years, or of unobserved heterogeneity by using a fixed or random effects approach as in Geil et al. (1997) would only result in even higher standard errors of the estimates, but not change the findings of the analysis.

Not surprisingly, chronic conditions (not explicitly given in the tables) increase the number of hospital trips massively, for men as well as for women. The same expected positive effect, though clearly lower in magnitude, can be seen (although also not reported) for handicapped persons. Distance is a significant element of hospitalization demand only for women in general, not for men and for the chronically ill. A major reason for this may the dense and efficient provision of ambulance transport and hospital beds in Germany, reducing travel costs. Moreover, hesitations about going to hospital may increase especially for women if this means to be split from the family for a longer period of time, due to greater distance and travel time. While for females, being married implies a significant rise in hospitalization, men's behaviour is not affected. This may of course result from child bearing in the case of wives. Moreover, from the perspective of traditional division of labour in the family, being married may stress the husband's role as supplier of the family, which may lead to higher individual opportunity costs of hospitalization than for a bachelor.

Education was a major element of the Grossman model which we have examined in a more differentiated way above. While formal education seems to decrease the number of hospital trips for men, it remains statistically insignificant for women. The variable health job which we introduced in order to cover job-related information about health independent from formal qualification, is significant in the female sample (in the male sample only significant in the simple NEGBIN case) and has a 
positive sign contradicting the basic Grossman assumption that better information about health issues leads to more efficient health production.

The general picture of our findings can be upheld when one turns to the respective estimation results for the chronically ill (Table 8). Economic incentives from insurance coverage seem to work even less in the case of chronically ill persons than for the total population. Minor differences between the results for the total sample and for the chronically ill occur when one looks at the consequences of education. Here, the negative effect of formal education for men disappears and even becomes slightly positive for secondary school. Nevertheless, for women, the negative impact of apprenticeship on hospitalization persists.

Those results were basically confirmed by the two-step approach of the hurdle model for the chronically ill (Table 9). While the men's decision on whether to go to hospital or not is again independent of their insurance coverage, publicly insured women show a slightly significant increased likelihood of being hospitalized at all. Nevertheless, the negative impact of public family member insurance remains valid. So do the positive and negative effects of marriage for women and men, respectively. When one looks at the decision on the actual number of hospital trips, one also finds the familiar effects of insurance for women, with voluntary and family membership in the public scheme reducing and the copayment regime increasing the number of hospital trips. Only for men in the subsample have we found the positive effects of voluntary public insurance and of AOK membership, which we expected according to theory.

The impact of distance is covered in greater detail by the hurdle model. Obviously, living a relatively long way from a hospital does not prevent hospitalization as such but only decreases the number of consecutive trips. The costs of hospitalization thus seem to be only important when it comes 
to the question of after-treatment, for instance, while the basic decision of going to hospital is more subject to actual medical need. Together with the low number of significant parameters in the first step of the hurdle estimation compared to the second, this supports our reciprocal view of the determinants of the two-step decision process given above.

One essential and extraordinarily robust finding of our estimations is the insignificance of income throughout the samples and model specifications. This is again contrary to economic expectation and casts some doubt on the relevance of incentives as formulated by the Grossman model in the case of hospital care. Another result which is as persistent throughout all our estimations (like the impact of being handicapped or married) is the positive effect of children on the number of hospital trips of men and women, be they chronically ill or not.

The control variables on job status and nationality (not given explicitly in the tables) confirmed our basic results from the other variables. While we found that being in the labour force does not affect one's likelihood to go to hospital in general, there was a clear distinction between different groups of occupation. Compared to the unemployed and to civil servants, blue and white collar workers as well as self-employed showed a negative effect, which vanished for the chronically ill females except for the second step in the hurdle model. Finally, there was a significantly higher number of hospital trips of non-western male foreigners in the total sample. In case of the chronically ill persons, however, foreigners did not show a behaviour different from the Germans.

\section{Conclusions}

In brief, one can thus summarize our findings in the following way: 
1) Typical factors of the Grossman investment model for health which are expected to drive demand for hospital care being part of health care, do not work according to theory: Age and income are insignificant for the individual's decision to go to hospital, while education has to be evaluated in a more differentiated way than the formal theoretical model does. Only bad physical shape, which is covered by the Handicap and Chronic variables in our empirical specification show significance and signs according to the Grossman model.

2) Insurance coverage basically does not affect individual behaviour concerning hospital trips. Here, women seem to be more likely to react to economic incentives than males. The impact of insurance decreases further with a person being chronically ill. The hurdle model suggests that the decision of whether to go to hospital or not is mainly determined by medical reasons, while economic incentives play some role only for the number of consecutive hospital trips.

3) Family structure and position in the labour market seem much more important for the individual decision on hospitalization than incentive schemes provided by insurance. Especially being married and having children affects men's and women's behaviour significantly.

As far as the field of health economics is concerned, our results thus show that a differentiated view of the demand for health care is necessary. This applies especially for factors which have been largely neglected by previous theoretical and empirical research: the decisive role of national institutional differences, gender and health status. It seems obvious now that the structure and the organization of national health insurance systems play a decisive role for the resulting economic incentives faced by an individual. In the German case, this means that the institutional settings do not foster "overconsumption" of hospital care services driven from the demand side, which seems a speciality if one compares Germany e. g. with the U.S. or Australia. For the current political 
discussion we therefore conclude that a change in the German health insurance system, aiming at a higher level of market-related private coverage, is not likely to curb the demand for hospital trips. We want to emphasize, however, that our results do not imply that there are no economic measures to control hospital demand. The difficulties of the system may be rooted in the double role of doctors as suppliers of medical care including hospitalization, and as specialists mainly deciding about the kind and amount of cure an individual needs (Evans and Walker, 1972; Evans, 1991). Recent studies by the German public insurance companies seem to indicate that it is the doctors who tend to abuse the health insurance system. They suggest that about $20 \%$ of all hospital trips in Germany could have been substituted by cheaper ambulatory services without any loss of quality of cure (Federal Association of AOKs, 1997). If the problem of public health is thus the incentive scheme on the supply side, political measures like limiting prices and introducing caps on hospital budgets may well be a better step in order to solve the financial problems of the current system. 


\section{References}

Acton, J. P. (1975), 'Nonmonetary factors in the demand for medical services: Some empirical evidence', Journal of Political Economy, 83, 595-614

Arnold, M., and D. Paffrath (1997), Krankenhaus-Report 1997, Gustav-Fischer-Verlag, Stuttgart

Arrow, K. J. (1963), 'Uncertainty and the welfare economics of medical care', American Economic Review, 53, 941-973

Atri, S., and K. Lahiri (1986), 'Quality change and the demand for hospital care: An econometric reexamination', Atlantic Economic Journal, 14, 4, 15-23

Bikker, J. A., and A. F. de Vos (1992), 'A regional supply and demand model for inpatient hospital care', Environment and Planning, 24, 1097-1116

Cameron, A. C., and P. K. Trivedi (1986), 'Econometric models based on count data: Comparisons and applications of some estimators and tests', Journal of Applied Econometrics, 1, 29-53

Cameron, A. C., and P. K. Trivedi (1991), 'The role of income and health risk in the choice of health insurance', Journal of Public Economics, 45, 1-28

Cameron, A. C., P. K. Trivedi, F. Milne, and J. Piggott (1988), 'A microeconometric model of the demand for health care and health insurance in Australia', Review of Economic Studies, 55, 85-106

Cropper, M. L. (1977), 'Health, investment in health, and occupational choice', Journal of Political Economy, 85, 1273-1294

Cutler, D. M. (1994), 'A guide to health care reform', Journal of Economic Perspectives, 8, 13-29

Cutler, D. M. (1995), 'The cost and financing of health care', American Economic Review, 85, 3237

Davis, K. (1971), 'Theories of hospital inflation: Some empirical evidence', Journal of Human Resources, 8, 181-201

van Doorslaer, E., and A. Wagstaff(1992), 'Equity in the delivery of health care: Some international comparisons', Journal of Health Economics, 11, 389-411

Dowd, B., R. Feldman, S. Cassou, and M. Finch (1991), Health plan choice and the utilization of health care services, Review of Economics and Statistics, 73, 85-93

Dranove, D., M. Shanley, and C. Simon (1992), 'Is hospital competition wasteful?' Rand Journal of Economics, 23, 247-262 
Evans, R. G. (1991), 'Supplier-induced demand: Some empirical evidence and implications', in: A. J. Culyer (ed.), The economics of health, vol.2, Elgar, Aldershot, 66-77

Evans, R. G., and H. D. Walker (1972), 'Information theory and the analysis of hospital cost structure', Canadian Journal of Economics, 5, 398-418

Federal Association of AOKs (1997), Presseservice Gesundheit, no. 6/97, Bonn, 14 April 1997

Federal Ministry of Health (1997a), 'Gesetzliche Krankenversicherung', http://www.BMGesundheit.de/gkv/ueberbl/unersi2.htm, Bonn, July 1997

Federal Ministry of Health (1997b), 'Fragen und Antworten zur Gesundheitsreform', http://www.BMGesundheit.de/gkv/neu/ubersi2.htm, Bonn, June 1997

Federal Ministry of Health (1997c), 'Gesetzliche Krankenversicherung in Zahlen', http://www.BMGesundheit.de/gkv/gkvzahl/gkvzahl.htm, Bonn, March 1997

Federal Ministry of Health (1997d), 'Informationen zur Krankenkassenwahl', http://www.BMGesundheit.de/gkv/kk-wahl/ubersi2.htm, Bonn, June 1997

Federal Ministry of Health (1997e), 'Neuordnung der gesetzlichen Krankenversicherung', http://www.BMGesundheit.de/gkv/neuord/ubersi6_htm, Bonn, March 1997

Feldstein, M. (1971), 'Hospital cost inflation: A study of nonprofit price dynamics', American Economic Review, 61, 853-872

Feldstein, M. (1977), 'Quality change and the demand for hospital care', Econometrica, 45, 16811702

Feldstein, M. (1995), 'The economics of health and health care: What have we learned? What have I learned?', American Economic Review, 85, 28-31

Fox, D. M. (1993), Power and illness: The failure and future of American health policy, University of California Press, Berkeley

Geil, P., A. Million, R. Rotte and K. F. Zimmermann (1997),'Economic incentives and hospitalization in Germany', Journal of Applied Econometrics, 12, 295-311

Ghosh, S. K. (1991), Econometrics. Theory and applications, Prentice Hall, Englewood Cliffs/NJ

Grossman, M. (1972), The demand for health: A theoretical and empirical investigation, NBER, New York

Grossman, M. (1982), 'The demand for health after a decade', Journal of Health Economics, 1, 1-3 
Hunt-McCool, J., B. F. Kiker, and Y. C. Ng (1994), 'Estimates of the demand for medical care under different functional forms', Journal of Applied Econometrics, 9, 201-218

IDW (Institut der Deutschen Wirtschaft) (1997), Zahlen zur wirtschaftlichen Entwicklung derBundesrepublik Deutschland 1997, Deutscher Institutsverlag, Cologne

Johnson, N. L., and S. Kotz (1969), Distributions in statistics: Discrete distributions, Wiley \& Sons, New York

Klarmann, H. E. (1969) 'Approaches to moderating the increases in medical care costs', Medical Care, 7, 175-190

Krupnick, A. J., and M. L. Cropper (1992), 'The effect of information on health risk valuations', Journal of Risk and Uncertainty, 5, 29-48

Lambert, D. (1992), 'Zero-inflated Poisson regression, with an application to defects in manufacturing', Technometrics, 34, 1-14

Manning, W. G., J. P. Newhouse, N. Duan, E. B. Keeler, A. Leibowitz, and M. S. Marquis (1987), 'Health insurance and the demand for medical care: Evidence from a randomized experiment', American Economic Review, 77, 251-277

McCullagh, P. and J. A. Nelder (1989), Generalized linear models, Chapman and Hall, London Mullahy, J. (1986), 'Specifications and testing in some modified count data models', Journal of Econometrics, 33, 341-365

Muurinen, J.-M. (1982), 'Demand for health. A generalized Grossman model', Journal of Health Economics, 1, 5-28

Newhouse, J. P. (1992), 'Medical care costs: How much welfare loss?', Journal of Economic Perspectives, 6, 3-21

Newhouse, J. P., and the Insurance Experiment Group (1993), Free for all? Lessons from the RAND health insurance experiment, Harvard University Press, Cambridge

Phelps, C.E. (1976), 'Demand for reimbursement insurance', in: R.N. Rosett (ed.), The role of health insurance in the health services sector, NBER, New York, 115-155

Pohlmeier, W., and V. Ulrich (1995), 'An econometric model of the two-part decision-making process in the demand for medical care', Journal of Human Resources, 30, 339-361

Propper, C. (1989), 'An econometric analysis of the demand for private health insurance in England and Wales', Applied Economics, 21, 777-792 
Rosett, R. N., and L. Huang (1972), 'The effect of health insurance on the demand for medical care', Journal of Political Economy, 80, 281-305

Tolley, G., D. Kenkel, and R. Fabian (eds.) (1994), Valuing health for policy: An economic approach, University of Chicago Press, Chicago

van Vliet, R. C. J. A., and E. K. A. van Doorslaer (1988), 'Disaggregation of the demand for hospital care', Applied Economics, 20, 969-984

Vuong, Q. H. (1989), 'Likelihood ratio tests for model selection and non-nested hypotheses', Econometrica, 57, 307-333

Wagner, G. G., R. V. Burkhauser, and F. Behringer (1993), 'The English language public use file of the German Socio-Economic Panel', Journal of Human Resources, 28, 429-433

Wagstaff, A. (1986), The demand for health. Some new empirical evidence', Journal of Health Economics, 5, 195-233

Wagstaff, A., and E. van Doorslaer (1992), 'Equity in the finance of health care: Some international comparisons', Journal of Health Economics, 11, 361-387

Weisbrod, B. A. (1991), 'The health quadrilemma: An essay on technological change, insurance, quality of care, and cost containment', Journal of Economic Literature, 29, 523-552

Winkelmann, R., and K. F. Zimmermann (1995), 'Recent developments in count data modelling: Theory and application', Journal of Economic Surveys, 9, 1-24

Zimmermann, K. F. (1993), 'Labour responses to taxes and benefits in Germany', in: A. B. Atkinson and G. V. Mogensen (eds.), Welfare and Work Incentives. A North European Perspective, Clarendon Press, Oxford, 192-240 
Table 1: Variables in the Data Set

\begin{tabular}{|c|c|}
\hline Variable & Description \\
\hline Age & Age of the individual in years \\
\hline Sex & $1=$ male \\
\hline Hospital trips & Yearly number of inpatient stays in hospital \\
\hline Private & $1=$ Full coverage by private health insurance \\
\hline Copayment & $\begin{array}{l}1=\text { Full coverage by private health insurance with copayment } \\
\text { obligation }\end{array}$ \\
\hline Public & $\begin{array}{l}1=\text { Public, i. e. non-private insurance scheme including those } \\
\text { insured voluntarily and as family members }\end{array}$ \\
\hline Voluntary & $1=$ Voluntarily in public insurance scheme \\
\hline Family & $\begin{array}{l}1 \text { = Public insurance scheme for non-working spouse and children } \\
\text { of paying members of public insurance }\end{array}$ \\
\hline $\mathrm{AOK}$ & $\begin{array}{l}1=\text { Public insurance in Allgemeine Ortskrankenkasse, the } \\
\text { insurance company legally obliged to accept all risks }\end{array}$ \\
\hline Additional & $\begin{array}{l}1=\text { Public insurance with voluntary additional coverage through a } \\
\text { private scheme }\end{array}$ \\
\hline Chronic & $1=$ Individual suffering from a chronic condition \\
\hline Handicap & $1=$ Individual being handicapped \\
\hline Income & Monthly net income of the household (DM) \\
\hline Distance & $1=$ Place of living is outside of a city center \\
\hline Married & $1=$ married \\
\hline Secondary & $1=$ Educational level being at least secondary school (Realschule) \\
\hline University & $\begin{array}{l}1=\text { Individual holding a degree from a university or technical } \\
\text { college }\end{array}$ \\
\hline Apprenticeship & $1=$ Individual having passed vocational training \\
\hline Health job & $1=$ Individual working in a health-related field \\
\hline In labour & $1=$ Individual being in the labour force, i. e. working or unemployed \\
\hline Blue collar & $1=$ Individual being a blue collar worker \\
\hline White collar & $1=$ Individual being a white collar worker \\
\hline Civil servant & $1=$ Individual being a civil servant \\
\hline Self-employed & $1=$ Individual being a self-employed \\
\hline Part-time & $1=$ Individual working part-time \\
\hline Western & $1=\mathrm{EU}, \mathrm{US}$, Canadian or Swiss national \\
\hline Nation else & $1=$ Other non-German nationals \\
\hline Children & Number of children below age 16 in the household \\
\hline
\end{tabular}


Table 2: Descriptive Statistics, total sample

All

Males

Females

Mean Stand. Mean Stand. Mean Stand.

Dev. Dev. Dev.

\begin{tabular}{lcccccc}
\hline Age & 48.53 & 8.76 & 49.77 & 8.76 & 47.37 & 8.61 \\
Sex & 0.49 & 0.50 & --- & --- & --- & --- \\
Hospital trips & 0.14 & 0.67 & 0.10 & 0.66 & 0.17 & 0.68 \\
Private & 0.09 & 0.29 & 0.12 & 0.33 & 0.06 & 0.24 \\
Copayment & 0.08 & 0.27 & 0.10 & 0.30 & 0.05 & 0.23 \\
Public & 0.92 & 0.26 & 0.90 & 0.30 & 0.95 & 0.21 \\
Voluntary & 0.10 & 0.30 & 0.16 & 0.37 & 0.05 & 0.21 \\
Family & 0.22 & 0.42 & 0.01 & 0.10 & 0.42 & 0.49 \\
AOK & 0.45 & 0.50 & 0.46 & 0.50 & 0.44 & 0.50 \\
Additional & 0.05 & 0.22 & 0.05 & 0.22 & 0.05 & 0.21 \\
Chronic & 0.20 & 0.40 & 0.19 & 0.40 & 0.21 & 0.41 \\
Handicap & 0.17 & 0.37 & 0.17 & 0.38 & 0.16 & 0.37 \\
Income & $3,616.25$ & $2,012.10$ & $3,659.18$ & $2,030.12$ & $3,575.54$ & $1,994.54$ \\
Distance & 0.87 & 0.33 & 0.87 & 0.33 & 0.87 & 0.33 \\
Married & 0.82 & 0.38 & 0.80 & 0.40 & 0.84 & 0.37 \\
Secondary & 0.43 & 0.49 & 0.44 & 0.50 & 0.41 & 0.49 \\
University & 0.08 & 0.27 & 0.11 & 0.31 & 0.05 & 0.21 \\
Apprenticeship & 0.60 & 0.49 & 0.65 & 0.48 & 0.55 & 0.50 \\
Health job & 0.01 & 0.12 & 0.01 & 0.09 & 0.02 & 0.14 \\
In labour & 0.80 & 0.40 & 0.98 & 0.10 & 0.62 & 0.49 \\
Blue collar & 0.40 & 0.49 & 0.57 & 0.50 & 0.24 & 0.42 \\
White collar & 0.26 & 0.44 & 0.23 & 0.42 & 0.28 & 0.45 \\
Civil servant & 0.06 & 0.23 & 0.09 & 0.28 & 0.03 & 0.16 \\
Self-employed & 0.06 & 0.24 & 0.08 & 0.28 & 0.04 & 0.21 \\
Part-time & 0.10 & 0.30 & 0.01 & 0.07 & 0.20 & 0.40 \\
Western & 0.14 & 0.34 & 0.16 & 0.36 & 0.12 & 0.32 \\
Nation else & 0.20 & 0.40 & 0.19 & 0.39 & 0.20 & 0.40 \\
Children & 0.60 & 0.49 & 0.58 & 0.49 & 0.62 & 0.49 \\
\hline & & & & & & \\
\hline
\end{tabular}


Table 3: Descriptive Statistics, chronically ill persons

All

Males

Females

$\begin{array}{ccccc}\text { Mean Stand. Mean Stand. Mean } & \text { Stand. } \\ \text { Dev. } & \text { Dev. } & \text { Dev. }\end{array}$

\begin{tabular}{lcccccc}
\hline Age & 51.64 & 8.04 & 53.06 & 8.01 & 50.41 & 7.85 \\
Sex & 0.47 & 0.50 & --- & --- & -- & --- \\
Hospital trips & 0.21 & 0.80 & 0.19 & 0.74 & 0.23 & 0.86 \\
Private & 0.10 & 0.30 & 0.13 & 0.34 & 0.07 & 0.27 \\
Copayment & 0.09 & 0.28 & 0.11 & 0.31 & 0.07 & 0.25 \\
Public & 0.91 & 0.28 & 0.89 & 0.31 & 0.94 & 0.24 \\
Voluntary & 0.10 & 0.30 & 0.16 & 0.37 & 0.04 & 0.20 \\
Family & 0.23 & 0.42 & 0.02 & 0.13 & 0.43 & 0.49 \\
AOK & 0.41 & 0.49 & 0.42 & 0.49 & 0.39 & 0.49 \\
Additional & 0.07 & 0.25 & 0.07 & 0.25 & 0.06 & 0.25 \\
Handicap & 0.24 & 0.43 & 0.26 & 0.44 & 0.22 & 0.41 \\
Income & $3,678.07$ & $2,103.31$ & $3,727.76$ & $2,250.48$ & $3,634.80$ & $1,965.60$ \\
Distance & 0.87 & 0.34 & 0.87 & 0.33 & 0.86 & 0.34 \\
Married & 0.85 & 0.35 & 0.86 & 0.35 & 0.85 & 0.36 \\
Secondary & 0.40 & 0.49 & 0.39 & 0.49 & 0.41 & 0.49 \\
University & 0.06 & 0.24 & 0.09 & 0.29 & 0.04 & 0.19 \\
Apprenticeship & 0.63 & 0.48 & 0.69 & 0.46 & 0.57 & 0.50 \\
Health job & 0.01 & 0.11 & 0.01 & 0.09 & 0.01 & 0.12 \\
In labour & 0.79 & 0.41 & 0.98 & 0.14 & 0.63 & 0.48 \\
Blue collar & 0.38 & 0.49 & 0.55 & 0.50 & 0.23 & 0.42 \\
White collar & 0.26 & 0.44 & 0.23 & 0.42 & 0.29 & 0.45 \\
Civil servant & 0.06 & 0.25 & 0.11 & 0.32 & 0.03 & 0.16 \\
Self-employed & 0.06 & 0.24 & 0.07 & 0.26 & 0.05 & 0.22 \\
Part-time & 0.11 & 0.32 & 0.01 & 0.15 & 0.21 & 0.41 \\
Western & 0.11 & 0.32 & 0.12 & 0.32 & 0.11 & 0.31 \\
Nation else & 0.16 & 0.37 & 0.16 & 0.36 & 0.16 & 0.37 \\
Children & 0.54 & 0.50 & 0.53 & 0.50 & 0.54 & 0.50 \\
\hline
\end{tabular}


Table 4: LRT Values for Splitting the Sample into Males and Females

\begin{tabular}{|c|c|c|c|c|}
\hline & Poisson & NEGBIN & $\mathrm{ZIP}(\tau)_{\text {normal }}$ & $\mathrm{ZIP}(\tau)_{\text {logistic }}$ \\
\hline $\begin{array}{l}\text { All } \\
\text { observations }\end{array}$ & $\begin{array}{c}304 \\
\left(\chi^{2}{ }_{32}=45.9\right)\end{array}$ & $\begin{array}{c}64 \\
\left(\chi_{33}^{2}=47.1\right)\end{array}$ & $\begin{array}{c}274 \\
\left(\chi_{33}^{2}=47.1\right)\end{array}$ & $\begin{array}{c}272 \\
\left(\chi_{33}^{2}=47.1\right)\end{array}$ \\
\hline Chro & $\begin{array}{c}90 \\
\left(\chi^{2}{ }_{31}=44.7\right)\end{array}$ & $\begin{array}{c}54 \\
\left(\chi_{32}^{2}=45.9\right)\end{array}$ & $\begin{array}{c}56 \\
\left(\chi_{32}^{2}=45.9\right)\end{array}$ & $\begin{array}{c}54 \\
\left(\chi_{32}^{2}=45.9\right)\end{array}$ \\
\hline
\end{tabular}

Likelihood ratio test values for testing the total sample estimation against the sum of separate (male and female) samples: $L R T=-2\left(\ln L_{\text {total }}-\sum \ln L_{i}\right)$ with $\mathrm{i}=1,2$ for the male and female sample, respectively. Critical $\chi^{2}$ value on the $5 \%$ level for the relevant number degrees of freedom in parentheses.

Table 5: Tests against the Poisson Model

\begin{tabular}{lcc} 
Poisson vs. NEGBIN & LRT & t-statistic for $\alpha$ \\
\hline Males, all & 1,608 & 18.36 \\
Females, all & 916 & 26.56 \\
Males, chronically ill & 374 & 8.71 \\
Females, chronically ill & 542 & 11.19 \\
\hline
\end{tabular}

\begin{tabular}{lcc} 
Poisson vs. ZIP( $\boldsymbol{\tau})$ & Vuong Statistic ZIP $(\tau)_{\text {normal }}$ & Vuong Statistic ZIP $(\tau)_{\text {logistic }}$ \\
\hline Males, all & 81.99 & 81.64 \\
Females, all & 43.62 & 44.16 \\
Males, chronically ill & 29.09 & 29.01 \\
Females, chronically ill & 30.44 & 30.54 \\
\hline
\end{tabular}

Likelihood ratio test values for testing the sample-specific Poisson estimation against the corresponding NEGBIN estimation. The critical $\chi^{2}{ }_{1}$ value on the $5 \%$ level is 3.84 . The critical value of the 
asymptotically standard normal distributed Vuong test statistic is 1.96 on the $5 \%$ level(Vuong, 1989). Values greater than the critical value lead to refusal of the Poisson model. 
Table 6: Relative Performance of the Selected Models

\begin{tabular}{lcccc} 
& NEGBIN & ZIP $(\tau)_{\text {normal }}$ & ZIP $(\tau)_{\text {logistic }}$ & $\begin{array}{c}\text { Hurdle } \\
\text { Poisson }\end{array}$ \\
\hline $\begin{array}{l}\text { Males, } \\
\text { all }\end{array}$ & 0.60 & 0.63 & 0.63 & --- \\
$\begin{array}{l}\text { Females, } \\
\text { all }\end{array}$ & 0.94 & 0.95 & 0.95 & --- \\
$\begin{array}{l}\text { Males, } \\
\text { chronically ill }\end{array}$ & 0.98 & 1.04 & 1.04 & 0.86 \\
$\begin{array}{l}\text { Females, } \\
\text { chronically ill }\end{array}$ & 1.14 & 1.22 & 1.22 & 0.98 \\
\hline
\end{tabular}

Akaike information criterion values (Ghosh, 1991, p.519): AIC $=-2(\operatorname{lnL}) / \mathrm{n}+2 \mathrm{k} / \mathrm{n}$ with $\mathrm{k}=$ number of parameters estimated and $\mathrm{n}=$ number of observations. 
Table 7: Selected Estimation Results for Males and Females, Total Sample

\begin{tabular}{|c|c|c|c|c|}
\hline & \multicolumn{2}{|c|}{ NEGBIN } & \multicolumn{2}{|c|}{$\mathrm{ZIP}(\tau)$} \\
\hline & Males & Females & Males & Females \\
\hline Age & $\begin{array}{l}0.475 \\
(1.40)\end{array}$ & $\begin{array}{c}0.607 * \\
(1.72)\end{array}$ & $\begin{array}{l}0.072 \\
(1.15)\end{array}$ & $\begin{array}{c}0.340 * * \\
(2.87)\end{array}$ \\
\hline $\operatorname{Age}^{2} \cdot 10^{-3}$ & $\begin{array}{l}-9.854 \\
(-1.38)\end{array}$ & $\begin{array}{c}-15.678 * * \\
(-2.04)\end{array}$ & $\begin{array}{l}-1.594 \\
(-1.22)\end{array}$ & $\begin{array}{c}-8.758 * * \\
(-3.36)\end{array}$ \\
\hline $\operatorname{Age}^{3} \cdot 10^{-4}$ & $\begin{array}{l}0.673 \\
(1.36)\end{array}$ & $\begin{array}{c}1.241 * * \\
(2.26)\end{array}$ & $\begin{array}{l}0.117 \\
(1.29)\end{array}$ & $\begin{array}{c}0.690 * * \\
(3.67)\end{array}$ \\
\hline Copayment & $\begin{array}{l}0.236 \\
(1.07)\end{array}$ & $\begin{array}{l}0.116 \\
(0.47)\end{array}$ & $\begin{array}{l}0.034 \\
(0.92)\end{array}$ & $\begin{array}{l}0.051 \\
(0.56)\end{array}$ \\
\hline Public & $\begin{array}{l}0.292 \\
(1.17)\end{array}$ & $\begin{array}{c}0.570 * * \\
(2.01)\end{array}$ & $\begin{array}{l}0.030 \\
(0.68)\end{array}$ & $\begin{array}{c}0.326 * * \\
(3.21)\end{array}$ \\
\hline Voluntary & $\begin{array}{l}0.133 \\
(0.95)\end{array}$ & $\begin{array}{l}-0.349 \\
(-1.60)\end{array}$ & $\begin{array}{l}0.039 \\
(1.40)\end{array}$ & $\begin{array}{c}-0.178 * * \\
(-2.47)\end{array}$ \\
\hline Family & $\begin{array}{l}-0.421 \\
(-0.95)\end{array}$ & $\begin{array}{c}-0.857 * * \\
(-6.04)\end{array}$ & $\begin{array}{l}-0.093 \\
(-1.34)\end{array}$ & $\begin{array}{c}-0.485 * * \\
(-10.73)\end{array}$ \\
\hline $\begin{array}{l}\text { Public } \\
\text { Additional }\end{array}$ & $\begin{array}{l}-0.303 \\
(-0.41)\end{array}$ & $\begin{array}{l}-0.581 \\
(-1.10)\end{array}$ & $\begin{array}{l}0.012 \\
(0.11)\end{array}$ & $\begin{array}{l}-0.246 \\
(-1.21)\end{array}$ \\
\hline Public $\bullet A O K$ & $\begin{array}{c}0.011 \\
(0.14)\end{array}$ & $\begin{array}{c}-0.246^{* *} \\
(-2.12)\end{array}$ & $\begin{array}{l}0.012 \\
(0.85)\end{array}$ & $\begin{array}{c}-0.144 * * \\
(-3.61)\end{array}$ \\
\hline $\begin{array}{l}\text { Voluntary• } \\
\text { Additional }\end{array}$ & $\begin{array}{l}0.559 \\
(0.71)\end{array}$ & $\begin{array}{l}0.433 \\
(0.59)\end{array}$ & $\begin{array}{l}0.015 \\
(0.13)\end{array}$ & $\begin{array}{l}0.199 \\
(0.69)\end{array}$ \\
\hline $\begin{array}{l}\text { Voluntary• } \\
\text { AOK }\end{array}$ & $\begin{array}{l}0.261 \\
(1.26)\end{array}$ & $\begin{array}{l}0.104 \\
(0.27)\end{array}$ & $\begin{array}{l}0.019 \\
(0.48)\end{array}$ & $\begin{array}{l}0.054 \\
(0.42)\end{array}$ \\
\hline $\begin{array}{l}\text { Family• } \\
\text { Additional }\end{array}$ & --- & $\begin{array}{l}0.654 \\
(1.16)\end{array}$ & --- & $\begin{array}{l}0.298 \\
(1.37)\end{array}$ \\
\hline Family•AOK & --- & $\begin{array}{l}0.218 \\
(1.46)\end{array}$ & --- & $\begin{array}{c}0.115^{* *} \\
(2.23)\end{array}$ \\
\hline Income $\bullet 10^{-5}$ & $\begin{array}{l}-0.880 \\
(-0.35)\end{array}$ & $\begin{array}{l}-0.962 \\
(-0.47)\end{array}$ & $\begin{array}{l}-0.037 \\
(-0.09)\end{array}$ & $\begin{array}{l}-0.449 \\
(-0.64)\end{array}$ \\
\hline
\end{tabular}




\begin{tabular}{|c|c|c|c|c|}
\hline Distance & $\begin{array}{l}-0.011 \\
(-0.09)\end{array}$ & $\begin{array}{c}-0.201 * \\
(-1.83)\end{array}$ & $\begin{array}{l}-0.026 \\
(-1.39)\end{array}$ & $\begin{array}{c}-0.121 * * \\
(-3.47)\end{array}$ \\
\hline Married & $\begin{array}{l}-0.069 \\
(-0.57)\end{array}$ & $\begin{array}{c}0.338 * * \\
(2.89)\end{array}$ & $\begin{array}{l}-0.032 \\
(-1.60)\end{array}$ & $\begin{array}{c}0.194 * * \\
(4.60)\end{array}$ \\
\hline Secondary & $\begin{array}{c}-0.296 * * \\
(-3.59)\end{array}$ & $\begin{array}{l}0.051 \\
(0.67)\end{array}$ & $\begin{array}{c}-0.038 * * \\
(-2.40)\end{array}$ & $\begin{array}{l}0.029 \\
(1.09)\end{array}$ \\
\hline $\begin{array}{l}\text { Apprentice- } \\
\text { ship }\end{array}$ & $\begin{array}{l}-0.047 \\
(-0.54)\end{array}$ & $\begin{array}{l}-0.095 \\
(-1.18)\end{array}$ & $\begin{array}{l}-0.009 \\
(-0.62)\end{array}$ & $\begin{array}{c}-0.560 * * \\
(-2.02)\end{array}$ \\
\hline University & $\begin{array}{c}-0.609 * * \\
(-3.18)\end{array}$ & $\begin{array}{l}-0.158 \\
(-0.75)\end{array}$ & $\begin{array}{c}-0.097 * * \\
(-3.01)\end{array}$ & $\begin{array}{l}-0.082 \\
(-1.04)\end{array}$ \\
\hline Health job & $\begin{array}{c}1.015^{* *} \\
(5.57)\end{array}$ & $\begin{array}{c}0.488 * * \\
(2.22)\end{array}$ & $\begin{array}{l}0.717 \\
(1.39)\end{array}$ & $\begin{array}{c}0.285 * * \\
(3.81)\end{array}$ \\
\hline In labour & $\begin{array}{l}-0.622 \\
(-1.56)\end{array}$ & $\begin{array}{l}-0.178 \\
(-1.02)\end{array}$ & $\begin{array}{l}-0.082 \\
(-1.37)\end{array}$ & $\begin{array}{c}-0.099 * \\
(-1.74)\end{array}$ \\
\hline Western & $\begin{array}{l}-0.059 \\
(-0.40)\end{array}$ & $\begin{array}{l}-0.201 \\
(-1.54)\end{array}$ & $\begin{array}{l}0.025 \\
(1.14)\end{array}$ & $\begin{array}{c}-0.087^{*} \\
(-1.93)\end{array}$ \\
\hline Nation else & $\begin{array}{l}0.200^{*} \\
(1.83)\end{array}$ & $\begin{array}{l}-0.155 \\
(-1.43)\end{array}$ & $\begin{array}{c}0.053 * * \\
(2.70)\end{array}$ & $\begin{array}{c}-0.067 * \\
(-1.82)\end{array}$ \\
\hline Children & $\begin{array}{c}0.329 * * \\
(3.72)\end{array}$ & $\begin{array}{c}0.550 * * \\
(6.52)\end{array}$ & $\begin{array}{c}0.043 * * \\
(2.69)\end{array}$ & $\begin{array}{c}0.293 * * \\
(8.24)\end{array}$ \\
\hline$\alpha$ & $\begin{array}{c}6.712 * * \\
(18.36)\end{array}$ & $\begin{array}{l}6.823 * * \\
(26.56)\end{array}$ & --- & --- \\
\hline$\tau$ & --- & --- & $\begin{array}{c}-4.786 * * \\
(-16.35)\end{array}$ & $\begin{array}{c}-1.140 * * \\
(-12.02)\end{array}$ \\
\hline $\ln L$ & $-4,495.3$ & $-7,365.6$ & $-4,689.6$ & $-7,425.7$ \\
\hline Nobs & 14,890 & 15,700 & 14,890 & 15,700 \\
\hline
\end{tabular}

${ }^{a}$ All estimations include a constant and control additionally for chronic condition, handicap and job status. ZIP $(\tau)$ results are given for the logistic model only. Its estimated coefficients do not differ from the normal model. t-values are given in parentheses. * and ** indicate significance of the coefficients on the $90 \%$ and the $95 \%$ level, respectively (two-sided test). $\alpha$ is the estimated parameter of the gamma-distribution in the NEGBIN model. $\tau$ is the estimated additional parameter of the ZIP model. 
Table 8: Selected Estimation Results for Males and Females, Chronically IIl ${ }^{\mathrm{a}}$

\begin{tabular}{|c|c|c|c|c|}
\hline & \multicolumn{2}{|c|}{ NEGBIN } & \multicolumn{2}{|c|}{$\mathrm{ZIP}(\tau)$} \\
\hline & Males & Females & Males & Females \\
\hline Age & $\begin{array}{l}-0.592 \\
(-0.63)\end{array}$ & $\begin{array}{l}0.128 \\
(0.21)\end{array}$ & $\begin{array}{l}-0.122 \\
(-0.94)\end{array}$ & $\begin{array}{l}0.055 \\
(0.82)\end{array}$ \\
\hline $\operatorname{Age}^{2} \cdot 10^{-3}$ & $\begin{array}{l}11.985 \\
(0.62)\end{array}$ & $\begin{array}{l}-4.740 \\
(-0.37)\end{array}$ & $\begin{array}{l}-2.329 \\
(-0.87)\end{array}$ & $\begin{array}{l}-1.485 \\
(-1.02)\end{array}$ \\
\hline $\mathrm{Age}^{3} \cdot 10^{-4}$ & $\begin{array}{l}-0.790 \\
(-0.61)\end{array}$ & $\begin{array}{l}0.449 \\
(0.50)\end{array}$ & $\begin{array}{l}-0.145 \\
(-0.80)\end{array}$ & $\begin{array}{l}0.121 \\
(1.18)\end{array}$ \\
\hline Copayment & $\begin{array}{l}0.265 \\
(0.70)\end{array}$ & $\begin{array}{c}0.629 * \\
(1.88)\end{array}$ & $\begin{array}{l}0.004 \\
(0.07)\end{array}$ & $\begin{array}{l}0.029 \\
(0.67)\end{array}$ \\
\hline Public & $\begin{array}{l}-0.026 \\
(-0.06)\end{array}$ & $\begin{array}{l}0.561 \\
(1.57)\end{array}$ & $\begin{array}{l}0.019 \\
(0.27)\end{array}$ & $\begin{array}{l}0.081 \\
(1.59)\end{array}$ \\
\hline Voluntary & $\begin{array}{c}0.578 * * \\
(1.99)\end{array}$ & $\begin{array}{l}-0.447 \\
(-1.49)\end{array}$ & $\begin{array}{l}0.070 \\
(1.49)\end{array}$ & $\begin{array}{l}-0.035 \\
(-1.00)\end{array}$ \\
\hline Family & $\begin{array}{c}-1.636 * * \\
(-2.01)\end{array}$ & $\begin{array}{c}-0.579 * * \\
(-3.06)\end{array}$ & $\begin{array}{c}-0.250 * * \\
(-2.10)\end{array}$ & $\begin{array}{c}-0.068 * * \\
(-2.42)\end{array}$ \\
\hline $\begin{array}{l}\text { Public• } \\
\text { Additional }\end{array}$ & $\begin{array}{l}0.033 \\
(0.06)\end{array}$ & $\begin{array}{l}-0.132 \\
(-0.35)\end{array}$ & $\begin{array}{l}-0.035 \\
(-0.43)\end{array}$ & $\begin{array}{l}-0.016 \\
(-0.45)\end{array}$ \\
\hline Public•AOK & $\begin{array}{l}-0.015 \\
(-0.11)\end{array}$ & $\begin{array}{l}-0.141 \\
(-1.04)\end{array}$ & $\begin{array}{l}-0.204 \\
(-0.84)\end{array}$ & $\begin{array}{l}-0.022 \\
(-1.46)\end{array}$ \\
\hline Income $\bullet 10^{-5}$ & $\begin{array}{l}-1.005 \\
(-0.20)\end{array}$ & $\begin{array}{l}0.711 \\
(0.19)\end{array}$ & $\begin{array}{l}-0.402 \\
(-0.53)\end{array}$ & $\begin{array}{l}0.260 \\
(0.75)\end{array}$ \\
\hline Distance & $\begin{array}{l}-0.154 \\
(-0.73)\end{array}$ & $\begin{array}{c}-0.315^{*} \\
(-1.94)\end{array}$ & $\begin{array}{l}-0.019 \\
(-0.63)\end{array}$ & $\begin{array}{l}-0.015 \\
(-0.87)\end{array}$ \\
\hline Married & $\begin{array}{l}-0.337 \\
(-1.36)\end{array}$ & $\begin{array}{l}0.252 \\
(1.37)\end{array}$ & $\begin{array}{c}-0.065^{*} \\
(-1.68)\end{array}$ & $\begin{array}{c}0.039 * \\
(1.78)\end{array}$ \\
\hline Secondary & $\begin{array}{l}0.292 \\
(1.36)\end{array}$ & $\begin{array}{l}0.197 \\
(1.62)\end{array}$ & $\begin{array}{c}0.053^{*} \\
(1.67)\end{array}$ & $\begin{array}{l}0.007 \\
(0.59)\end{array}$ \\
\hline $\begin{array}{l}\text { Apprentice- } \\
\text { ship }\end{array}$ & $\begin{array}{l}-0.064 \\
(-0.37)\end{array}$ & $\begin{array}{c}-0.275^{* *} \\
(-2.19)\end{array}$ & $\begin{array}{l}0.019 \\
(0.72)\end{array}$ & $\begin{array}{c}-0.036^{* *} \\
(-2.10)\end{array}$ \\
\hline
\end{tabular}




\begin{tabular}{|c|c|c|c|c|}
\hline University & $\begin{array}{l}-0.556 \\
(-1.53)\end{array}$ & $\begin{array}{c}-1.350 * \\
(-1.84)\end{array}$ & $\begin{array}{l}-0.080 \\
(-1.42)\end{array}$ & $\begin{array}{l}-0.103 \\
(-1.46)\end{array}$ \\
\hline In labour & $\begin{array}{l}-0.691 \\
(-1.26)\end{array}$ & $\begin{array}{l}-0.182 \\
(-0.39)\end{array}$ & $\begin{array}{l}-0.107 \\
(-1.22)\end{array}$ & $\begin{array}{l}0.010 \\
(0.28)\end{array}$ \\
\hline Western & $\begin{array}{l}-0.188 \\
(-0.61)\end{array}$ & $\begin{array}{l}-0.188 \\
(-0.92)\end{array}$ & $\begin{array}{l}0.038 \\
(0.96)\end{array}$ & $\begin{array}{l}-0.008 \\
(-0.40)\end{array}$ \\
\hline Nation else & $\begin{array}{l}0.079 \\
(0.30)\end{array}$ & $\begin{array}{l}-0.236 \\
(-1.20)\end{array}$ & $\begin{array}{l}0.048 \\
(1.29)\end{array}$ & $\begin{array}{l}-0.009 \\
(-0.44)\end{array}$ \\
\hline Children & $\begin{array}{c}0.475^{* *} \\
(2.80) \\
\end{array}$ & $\begin{array}{c}0.491 * * \\
(3.62)\end{array}$ & $\begin{array}{c}0.062 * \\
(1.88) \\
\end{array}$ & $\begin{array}{c}0.036^{*} \\
(1.85) \\
\end{array}$ \\
\hline$\alpha$ & $\begin{array}{c}4.032 * * \\
(8.71)\end{array}$ & $\begin{array}{c}3.610 * * \\
(11.19)\end{array}$ & --- & --- \\
\hline$\tau$ & --- & --- & $\begin{array}{c}-5.661 * * \\
(-3.95)\end{array}$ & $\begin{array}{c}-9.786 * * \\
(-2.98)\end{array}$ \\
\hline $\ln L$ & $-1,229.8$ & $-1,646.6$ & $-1,305.8$ & $-1,769.5$ \\
\hline Nobs & 2,562 & 2,944 & 2,562 & 2,944 \\
\hline
\end{tabular}

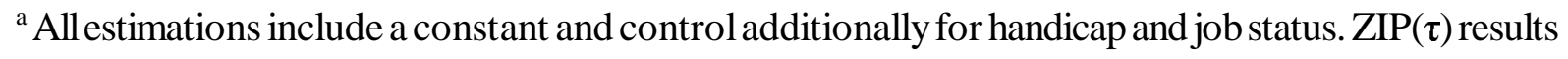
are given for the logistic model only. Its estimated coefficients do not differ from the normal model. tvalues are given in parentheses. $*$ and $* *$ indicate significance of the coefficients on the $90 \%$ and the $95 \%$ level, respectively (two-sided test). $\alpha$ is the estimated parameter of the gamma-distribution in the NEGBIN model. $\tau$ is the estimated additional parameter of the ZIP model. 
Table 9: Selected Estimation Results for the Hurdle Poisson Model, Chronically IIl ${ }^{\mathrm{a}}$

\begin{tabular}{|c|c|c|c|c|}
\hline & \multicolumn{2}{|c|}{ Males } & \multicolumn{2}{|c|}{ Females } \\
\hline & 1st step & 2nd step & 1st step & 2nd step \\
\hline Age & $\begin{array}{l}-0.163 \\
(-0.26)\end{array}$ & $\begin{array}{l}-0.043 \\
(-0.03)\end{array}$ & $\begin{array}{l}0.010 \\
(0.02)\end{array}$ & $\begin{array}{l}0.088 \\
(0.16)\end{array}$ \\
\hline $\mathrm{Age}^{2} \cdot 10^{-3}$ & $\begin{array}{l}2.012 \\
(0.15)\end{array}$ & $\begin{array}{l}5.230 \\
(0.18)\end{array}$ & $\begin{array}{l}-2.945 \\
(-0.25)\end{array}$ & $\begin{array}{l}-0.196 \\
(-0.02)\end{array}$ \\
\hline $\operatorname{Age}^{3} \cdot 10^{-4}$ & $\begin{array}{l}-0.047 \\
(-0.05)\end{array}$ & $\begin{array}{l}-0.631 \\
(-0.33)\end{array}$ & $\begin{array}{l}0.353 \\
(0.42)\end{array}$ & $\begin{array}{l}-0.049 \\
(-0.06)\end{array}$ \\
\hline Copayment & $\begin{array}{l}-0.103 \\
(-0.28)\end{array}$ & $\begin{array}{l}1.155 \\
(1.21)\end{array}$ & $\begin{array}{l}0.166 \\
(0.40)\end{array}$ & $\begin{array}{c}0.925 * * \\
(2.79)\end{array}$ \\
\hline Public & $\begin{array}{l}0.178 \\
(0.41)\end{array}$ & $\begin{array}{l}-0.046 \\
(-0.06)\end{array}$ & $\begin{array}{c}0.755^{*} \\
(1.70)\end{array}$ & $\begin{array}{l}0.150 \\
(0.42)\end{array}$ \\
\hline Voluntary & $\begin{array}{l}0.276 \\
(1.12)\end{array}$ & $\begin{array}{c}0.648^{*} \\
(1.83)\end{array}$ & $\begin{array}{l}-0.245 \\
(-0.84)\end{array}$ & $\begin{array}{c}-0.597 * \\
(-1.85)\end{array}$ \\
\hline Family & $\begin{array}{l}-1.018 \\
(-1.18)\end{array}$ & $\begin{array}{l}-5.028 \\
(-0.04)\end{array}$ & $\begin{array}{c}-0.585 * * \\
(-3.45)\end{array}$ & $\begin{array}{c}-0.284 * \\
(-1.81)\end{array}$ \\
\hline $\begin{array}{l}\text { Public• } \\
\text { Additional }\end{array}$ & $\begin{array}{l}-0.422 \\
(-0.79)\end{array}$ & $\begin{array}{l}0.298 \\
(0.46)\end{array}$ & $\begin{array}{l}-0.151 \\
(-0.43)\end{array}$ & $\begin{array}{l}0.124 \\
(0.29)\end{array}$ \\
\hline Public•AOK & $\begin{array}{l}-0.150 \\
(-1.12)\end{array}$ & $\begin{array}{c}0.503 * * \\
(3.30)\end{array}$ & $\begin{array}{l}-0.190 \\
(-1.58)\end{array}$ & $\begin{array}{l}0.077 \\
(0.59)\end{array}$ \\
\hline Income $\bullet 10^{-5}$ & $\begin{array}{l}-3.227 \\
(-0.71)\end{array}$ & $\begin{array}{l}7.198 \\
(1.13)\end{array}$ & $\begin{array}{l}2.838 \\
(1.09)\end{array}$ & $\begin{array}{l}-4.956 \\
(-1.25)\end{array}$ \\
\hline Distance & $\begin{array}{l}-0.027 \\
(-0.16)\end{array}$ & $\begin{array}{c}-0.378^{*} \\
(-1.69)\end{array}$ & $\begin{array}{l}-0.084 \\
(-0.56)\end{array}$ & $\begin{array}{c}-0.700 * * \\
(-4.44)\end{array}$ \\
\hline Married & $\begin{array}{c}-0.343 * \\
(-1.82)\end{array}$ & $\begin{array}{l}0.220 \\
(0.59)\end{array}$ & $\begin{array}{c}0.351 * * \\
(2.19)\end{array}$ & $\begin{array}{l}-0.125 \\
(-0.70)\end{array}$ \\
\hline Secondary & $\begin{array}{c}0.284 * \\
(1.80)\end{array}$ & $\begin{array}{l}0.179 \\
(0.64)\end{array}$ & $\begin{array}{l}0.018 \\
(0.17)\end{array}$ & $\begin{array}{c}0.463 * * \\
(4.05)\end{array}$ \\
\hline $\begin{array}{l}\text { Apprentice- } \\
\text { ship }\end{array}$ & $\begin{array}{l}0.147 \\
(0.94)\end{array}$ & $\begin{array}{c}-0.398 * \\
(-1.93)\end{array}$ & $\begin{array}{c}-0.292 * * \\
(-2.36)\end{array}$ & $\begin{array}{l}-0.188 \\
(-1.45)\end{array}$ \\
\hline
\end{tabular}




\begin{tabular}{lcccc} 
University & -0.391 & -0.320 & -0.848 & -3.581 \\
& $(-1.31)$ & $(-0.55)$ & $(-0.83)$ & $(-0.07)$ \\
In labour & -0.312 & -0.405 & 0.078 & $-1.153^{*}$ \\
& $(-0.71)$ & $(-1.33)$ & $(0.28)$ & $(-1.89)$ \\
Western & 0.347 & $-2.105^{* *}$ & -0.027 & $-0.566^{* *}$ \\
& $(1.60)$ & $(-4.03)$ & $(-0.15)$ & $(-2.23)$ \\
Nation else & 0.322 & $-0.621^{* *}$ & -0.011 & $-0.654^{* *}$ \\
& $(1.50)$ & $(-2.11)$ & $(-0.07)$ & $(-3.10)$ \\
Children & $0.268 *$ & $0.591^{* *}$ & $0.269 * *$ & $0.817^{* *}$ \\
& $(1.87)$ & $(2.52)$ & $(2.27)$ & $(5.03)$ \\
\hline \multirow{2}{*}{$\ln \mathrm{M}$} & $-1,051.5$ & & $-1,396.0$ & \\
Nobs & 2,562 & & 2,944 & \\
\hline
\end{tabular}

${ }^{\text {a }}$ All estimations include a constant and control additionally for handicap and job status. t-values are given in parentheses. * and $* *$ indicate significance of the coefficients on the $90 \%$ and the $95 \%$ level, respectively (two-sided test). 